\title{
Veneer and Plywood
}

$\mathrm{F}^{\text {oi }}$ $R$ veneers and plywood, some of the hard tropical timbers, often showing beautiful colouring and figuring, are becoming better known. Research on wood for veneer and plywood has been carried out for some time at the Research Institute at Dehra Dun. In Indian Forest Records (Economy Series, 20, 14. Delhi : Manager of Publications, Dec. 1934), Mr. W. Nagle, who is in charge of the Woodworking Section, discusses the "Testing of Indian Timbers for Veneer and Plywood". The purpose of the monograph is "to assist, as far as possible, the advancement of the plywood industry in India, and to further the use of indigenous timbers for veneer and plywood work".

Only those who have followed the development in the use of plywood during the last two decades will have a conception of the variety of purposes to which it is put at the present day. The author reminds the reader that the art of veneering was practised by, and certain forms of laminated construction were used by, the ancient Egyptians. But in Great Britain and for many centuries in Europe, solid wood was used both in house construction and for furniture. Modern demands for luxury articles at a cheap price have assisted and encouraged the use of plywood; but it would be misleading to think that the great demand for this material has been the result of any consideration for the conservation of valuable timbers. The truth is that at the present day every country which possesses areas of forest containing valuable, that is, luxury timbers is, by means of research work and otherwise, endeavouring to place them on the world markets.
It is well known that plywood has come into use in the manufacture of furniture and panelling. But it is worthy of placing on record the following list of other articles which are nowadays formed or built out of this fabricated material : cabin trunks, suit cases, perambulators, and even musical instruments such as violins and mandolins are made of either veneer or plywood. The modern motor-car has considerable amounts of plywood in its make-up, for example, floor boards, hood-stays, body-work, roofing and panelling. Other plywood or veneered articles in common use are chairs, theatre seats, wall panelling and ceilings, screen scenery and stage buildings for the cinema industry and theatres, railway carriages, dining saloons and 'sleepers'. The modern ship is fitted with plywood tables, bulkheads and general appointments. Parts of motor-boats, canoes and life-boats are often constructed of the same material also aeroplanes and airships. Finally, chests are now made for tea, opium, cement, rubber, etc.; as also fruit and cigarette boxes.

It will be obvious that the above list is capable of indefinite extension. That it has reached its present dimensions gives evidence of the considerable amount of research and experimental work which has been carried out xluring the past few decades.

Mr. Nagle's monograph is based on research carried out during the past ten years with Indian timbers, upon which little was known as to their suitability or otherwise for veneers and plywood. It is technical in character, with a number of interesting photographs, and deals with some forty-two Indian timber trees.

\section{Genetics of Size and Form Factors}

$\mathrm{T}^{\mathrm{n}}$ HE problems of size and form inheritance are more difficult than many other problems in genetics, partly because the character units cannot usually be directly observed; they are often represented by multiple factors in the germ plasm, and they are also obscured by fluctuations.

Messrs. Sinnott and Dunn (Biol. Reviews, 10, No. 2) have summarised our knowledge of the effects of genes on the development of size and form in plants and animals. Their summary is particularly useful because they emphasise the developmental and physiological aspects of size inheritance, although making it clear that fixed genic differences are involved. They point out that some dwarf types both in plants and animals are due to single factors, while many other size differences are due to several multiple factors. The differences may be in cell size, as in some of the polyploid and trisomic forms, or in cell number, or to both acting together. Size genes may depend upon general developmental differences controlled by particular metabolic rates.

In races of large rabbits the rate of cell division very early shows itself to be more rapid, and there is evidence that such races have a higher concentra- tion of sulphydryl. Differences in fruit size in tomato varieties are due to differences both in cell number and cell size. Up till the time the flower opens, all the tissues of the ovary are meristematic. Sub. sequent growth is due to increase in size of the cells. In large-fruited varieties the ovary is larger, but cell enlargement is also carried much further. There appears to be a particular schedule or pattern of growth, involving both cell size and cell number, in each variety. The study of the inheritance of size of parts or organs involves heterogonic growth and Goldschmidt's physiological theory of heredity.

The conception of genic balance is involved, as in the trisomic Daturas, where the genes in one chromosome increase and those in another decrease the size of the pith, while other chromosomes affect the relative amounts of xylem and phloem. Thus while size genes may be general in their action, they may also have a special influence on certain parts. As shown by studies of inheritance of fruit shape in Cucurbita and the combs of fowls, as well as the proportions between various bones, it is evident that shape factors usually affect not single dimensions but two or three dimensions, through differences in growth rate. 